\title{
Lynch Syndrome Patients with Limited Family History Identified in a Laboratory Setting: A Descriptive Study
}

\author{
Michelle Landon \\ Richard Wenstrup \\ Myriad Genetic Laboratories, Inc., Salt Lake City, Utah, USA
}

\section{Key Words}

Lynch syndrome - Genetic testing - Testing criteria .

Bethesda guidelines · Hereditary cancer syndromes
These results suggest that cancer diagnosis under the age of 50 years is an insufficiently sensitive predictor of hereditary cancer susceptibility.

\begin{abstract}
Objective: Patients diagnosed with colorectal cancer before the age of 50 years are recommended for Lynch syndrome (LS) testing according to current clinical guidelines. However, many patients are not identified because of the stringent guidelines on existing diagnostic criteria. The aim of this analysis was to evaluate the ability of existing criteria to adequately ascertain patients appropriate for LS genetic testing. Method: To determine whether existing clinical diagnostic criteria underascertain individuals who would be appropriate candidates for hereditary cancer risk assessment, we stratified the detection rate of deleterious mismatch repair (MMR) mutations in 9,109 patients with a personal history of colorectal cancer who were diagnosed between the ages of 30 and 74 years with little or no family history suggestive of LS by 5-year age-at-detection intervals. Results: There was little difference in the aggregate positive mutation rate in individuals diagnosed between the ages of 50 and 59 years compared to the positive mutation rate in patients diagnosed before the age of 50 years. Conclusion:
\end{abstract}

\section{Introduction}

Lynch syndrome (LS) is an autosomal-dominant tumor syndrome caused by functional loss of the DNA mismatch repair (MMR) system due to mutations in MMR genes (MLH1, MSH2, MSH6, and PMS2) or the EPCAM gene upstream of MSH2 [1]. LS is the most common hereditary colorectal cancer (CRC) syndrome, accounting for $2-4 \%$ of all CRC and for $2 \%$ of endometrial cancers (EC) [2], with a prevalence of 1 in 300-500 individuals in the general population [3]. Patients with LS have an elevated risk for CRC and EC, with lifetime risks of 82 and $71 \%$, respectively, compared to 5 and $2.6 \%$, respectively, in the general population. These patients also have an increased susceptibility for gastric, urothelial, ovarian, pancreatic, and sebaceous gland cancers, among others [4].

Early identification of MMR mutation carriers is a key component to risk-reducing treatment for affected patients. LS carriers are more likely to be diagnosed with

\begin{tabular}{ll}
\hline KARGER 125/5 & $\begin{array}{l}\text { ○ 2015 S. Karger AG, Basel } \\
0030-2414 / 15 / 0894-0221 \$ 39.50 / 0 \quad \text { Karger }\end{array}$ \\
E-Mail karger@karger.com & $\begin{array}{l}\text { This is an Open Access article licensed under the terms of the } \\
\text { Creative Commons Attribution-NonCommercial 3.0 Un- } \\
\text { ported license (CC BY-NC) (www.karger.com/OA-license), } \\
\text { applicable to the online version of the article only. Distribu- } \\
\text { tion permitted for non-commercial purposes only. }\end{array}$
\end{tabular}

Michelle Landon

Myriad Genetic Laboratories, Inc 320 Wakara Way

Salt Lake City, UT 84108 (USA)

E-Mail mlandon@myriad.com 
CRC at an early age, with an average age at onset of 58 years compared to 69 years in sporadic cases [5]. Adenomas also advance more rapidly (less than 5 years) in patients with LS who consequently require more frequent colonoscopies to prevent interval cancers $[6,7]$. In addition, LS carriers have a high risk of developing a second primary cancer compared to the general population [8]. Given the high prevalence and increased cancer risk for LS patients, it is important that effective diagnostic procedures are in place for the early identification of families with pathogenic MMR mutations.

Current guidelines for identifying patients with CRC who should be tested for MMR mutations are based on two factors: (1) tumor testing using immunohistochemistry (IHC) or microsatellite markers, or (2) personal and family history of LS-associated cancers. Tumor tissue in LS patients typically displays signs of high microsatellite instability (MSI) and reduced or lost expression of at least one MMR protein, as revealed by IHC staining. Usually, only patients with these tumor tissue indicators are chosen for MMR gene mutation analysis. However, high MSI and IHC, whose sensitivities range from 77 to $93 \%$ for the different MMR genes, are not always available to patients $[9,10]$. Furthermore, the specificity of MSI for LS is low, with $10-15 \%$ of sporadic CRC and $15-20 \%$ of sporadic EC displaying MSI [11]. In fact, a review of MSI, IHC, and genetic testing by the EGAPP (Evaluation of Genomic Applications in Practice and Prevention) working group found sufficient evidence to recommend offering genetic testing for Lynch syndrome to individuals with newly diagnosed colorectal cancer [10].

This lack of specificity in these screening methods has also led to the broader use of clinical criteria to screen for patients with a higher likelihood of an MMR gene mutation. The Bethesda guidelines were adopted in 1997 and revised in 2004 to consider younger age at onset and family history as factors for LS genetic testing $[12,13]$. According to these guidelines, patients diagnosed with CRC under the age of 50 years are considered appropriate for genetic testing without additional family history [13]. Patients with CRC and one first-degree relative or multiple first- and second-degree relatives with at least one early CRC diagnosis are also considered appropriate for testing according to these guidelines [14]. Given the prevalence of LS, it is estimated that these stringent guidelines on early diagnosis and family history likely exclude approximately $25 \%$ of patients with LS, particularly since the mean age at colon cancer diagnosis of LS patients is 58 years $[5,9]$.

The aim of this analysis is to determine the sensitivity of these existing clinical diagnostic criteria in ascertaining individuals for LS genetic testing. Although the diagnostic value of the Bethesda guidelines has been previously investigated, these studies have only assessed small cohorts with a limited investigation of $M L H 1 / M L H 2$ mutations [15-18]. Therefore, the present analysis examined a large population of patients with a personal history of CRC who underwent genetic testing for the four genes currently known to be associated with LS. The age of CRC diagnosis was correlated with the identification of an MMR mutation, specifically focusing on patients with little to no family history.

\section{Materials and Methods}

We queried a commercial laboratory database for patients with a personal diagnosis of CRC who were tested for LS from September 2006 to October 2013 (full cohort). The minimum eligibility requirements included all patients who underwent full-sequence and large-rearrangement analysis of $M L H 1$ and $M S H 2$ as well as full-sequence analysis of MSH6. Patients who underwent additional full-sequence and large-rearrangement analysis of PMS2 and large-rearrangement analysis of MSH6 and EPCAM were also eligible for inclusion. Patients tested for only one of the $M M R$ genes (based on IHC test results) or with a known family mutation were excluded. All patient data regarding clinical history was obtained by health care provider reports on test requisition forms.

The subsets of patients with no family history of CRC (no family history) or with only a single first- or second-degree relative diagnosed with CRC or EC over the age of 50 years (limited family history) were selected for further analysis. Patients in these individual subsets as well as those in the combined subset (no family history and limited family history) were stratified by age-atdiagnosis in 5-year intervals. Only patients diagnosed between the ages of 30 and 74 years are presented here, as the number of patients diagnosed before the age of 30 or after the age of 74 was too small to be statistically significant when stratified.

\section{Results}

This analysis identified 15,469 patients with a personal history of CRC who were tested for LS in the time period of this study. Of these patients, 1,688 (10.9\%) had at least one pathogenic mutation. Figure 1 shows that the majority of pathogenic mutations were identified in MLH1 (40.3\%) and MSH2 (38.6\%). The remaining mutations were identified in MSH6 (14.3\%), PMS2 (5.6\%), and EPCAM (1.2\%). Figure 2 shows the distribution of mutations in patients with LS who were diagnosed with CRC before and after the age of 60 years. Although the average age at CRC onset in LS carriers is 58 years, we used the age of 60 years as a reasonably close approximation here, since patients were stratified in 5-year intervals for this 
Fig. 1. Distribution of LS gene mutations for all mutation-positive patients $(\mathrm{n}=$ $1,688)$.

Fig. 2. Stratification of LS gene mutations by age at onset $<60$ years. Only mutations in patients who provided age information on the test request form are included $(\mathrm{n}=$ $1,643)$.
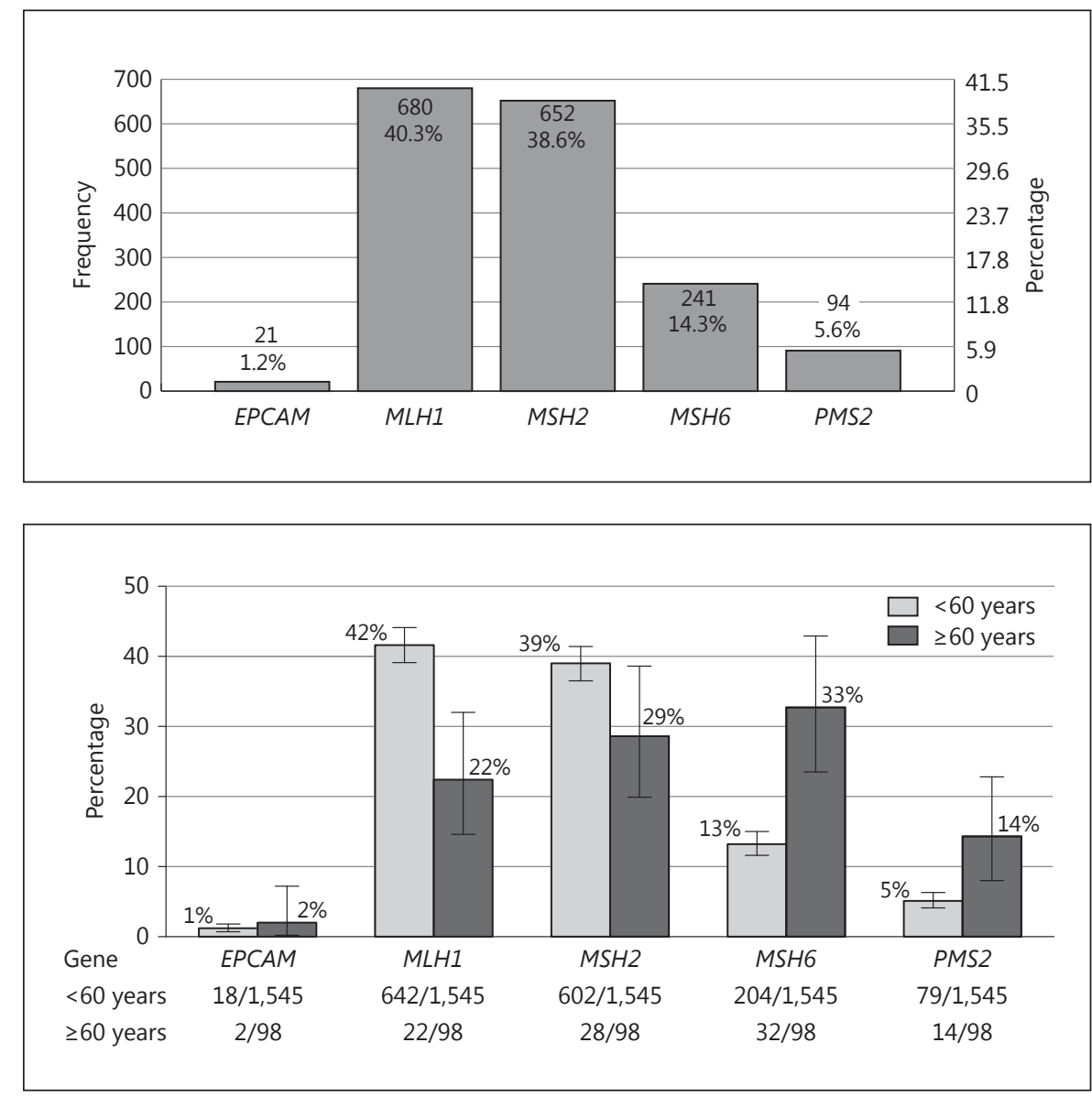

study. Only MSH6 had a statistical difference $(\mathrm{p}<0.001)$ in the proportion of mutations identified in patients diagnosed with CRC before and after the age of 60 years.

The combined subset of patients with no family history and limited family history in the age group analyzed (30-74 years) consisted of 9,109 patients or $58.9 \%$ of the full cohort. The positive rates for MMR mutations in this combined subset are stratified by patient age at diagnosis in 5-year intervals in figure 3, with the details of each age group shown in table 1 . The highest positive rate in this combined cohort was observed in patients diagnosed between the age of 30 and 34 years, with a $9.6 \%$ positive rate. Figure 3 shows the positive rates in patients diagnosed between the ages of 35 and 59 years, which range from 4.7 to $6.9 \%$ and show no significant trend with age. The positive rate begins to decrease at the age of 60 years, dropping from $4.3 \%$ in the age group of $60-64$ years to $2.7 \%$ in the age group of 70-74 years.

Figure 3 also shows the positive rates for each individual subset of patients. Among patients with no fami- ly history of CRC $(n=6,129)$, the highest positive rate $(9.0 \%)$ is again observed in the youngest age group. There is very little change in the positive rate for patients with no family history who were diagnosed between the ages of 35 and 54, which ranges from 4.3 to $5.5 \%$. There is a slight increase to a positive rate of $7.6 \%$ for patients diagnosed between the ages of 55 and 59 years. Similar to the observation in the combined subset, the positive rates decrease steadily with age for patients diagnosed over the age of 60 years.

The subset of patients with limited family history was also examined $(n=2,980)$. Figure 3 shows that patients diagnosed between the ages of 30 and 34 years had a positive rate of $11.7 \%$. This decreases to a plateau, revealing very little change in the positive rates for patients diagnosed between the ages of 45 and 59 years, which range from 5.6 to $6.2 \%$. An overall drop was again observed in patients who were diagnosed above the age of 60 years, with positive rates ranging from 2.7 to $4.0 \%$ in this limited family history population. 


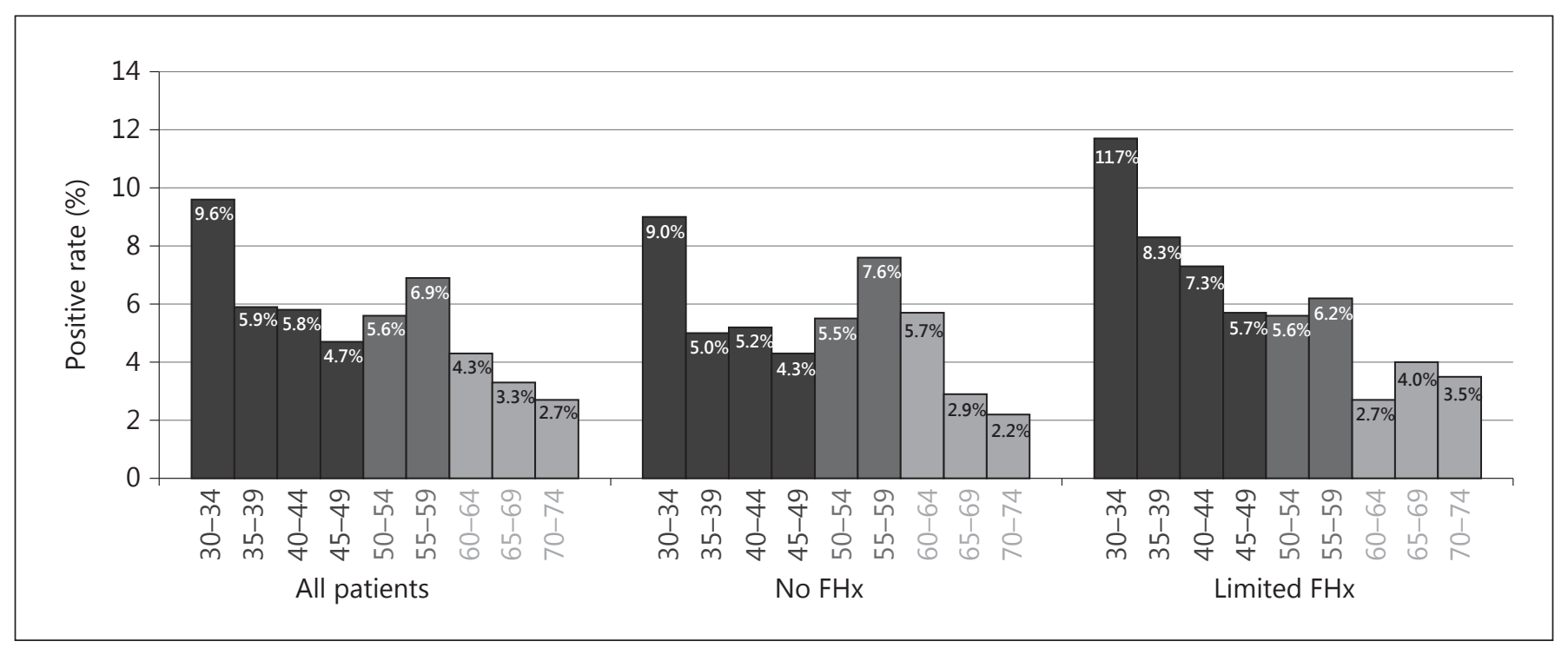

Fig. 3. Positive rate of LS mutations by age for all patients, patients with no family history (no FHx), or patients with one family member diagnosed with early-onset CRC/EC (limited FHx).

Table 1. Mutation-positive rate by age for patients with no or a limited family history

\begin{tabular}{|c|c|c|c|c|c|c|c|c|c|}
\hline $\begin{array}{l}\text { Age at CRC } \\
\text { diagnosis, } \\
\text { years }\end{array}$ & \multicolumn{3}{|c|}{ All patients } & \multicolumn{3}{|c|}{ No family history } & \multicolumn{3}{|c|}{ Limited family history } \\
\hline $30-34$ & 771 & 74 & 9.6 & 608 & 55 & 9.0 & 163 & 19 & 11.7 \\
\hline $35-39$ & 1,460 & 86 & 5.9 & 1,060 & 53 & 5.0 & 400 & 33 & 8.3 \\
\hline $40-44$ & 1,983 & 116 & 5.8 & 1,410 & 74 & 5.2 & 573 & 42 & 7.3 \\
\hline $55-59$ & 547 & 38 & 6.9 & 290 & 22 & 7.6 & 257 & 16 & 6.2 \\
\hline $60-64$ & 399 & 17 & 4.3 & 212 & 12 & 5.7 & 187 & 5 & 2.7 \\
\hline $65-69$ & 239 & 8 & 3.3 & 138 & 4 & 2.9 & 101 & 4 & 4.0 \\
\hline $70-74$ & 149 & 4 & 2.7 & 92 & 2 & 2.2 & 57 & 2 & 3.5 \\
\hline
\end{tabular}

\section{Discussion}

Several studies have suggested that the revised Bethesda guidelines are too complex and restrictive $[19,20]$, which may hinder their application in clinical practice [21]. Identifying patients who have LS after their first cancer diagnosis presents the opportunity for risk-reducing strategies such as increased surveillance or prophylactic surgery. Proponents have advocated a variety of alternate screening strategies, including mathematical algorithms to predict MMR gene mutation carriers based on personal and family history [22] and broader, even universal, tumor mutation testing $[14,19,23,24]$. However, the inconsistency between pathologists in evaluating the histopathological features of MSI tumors [25-28] highlights the limitations of these clinical strategies. Furthermore, the use of MSI and IHC as screening tools for MMR genetic testing delays medical management decisions and excludes $7-23 \%$ of LS carriers, based on test sensitivity alone.

Current clinical guidelines indicate that patients diagnosed with CRC before the age of 50 years are appropriate for MMR mutation testing; however, the average age of CRC diagnosis in LS carriers is 58 years [5]. In order to 
measure the sensitivity of the $<50$ cutoff, the positive rates of mutations were examined in patients with a personal diagnosis of CRC. This analysis included only patients with limited or no family history of CRC to eliminate family history as a confounding variable. Figure 3 shows that the positive rate of mutations in all patients diagnosed between the ages of 50 and 59 years does not decrease relative to patients who were diagnosed before the age of 50 years. This is observed for patients with no family history as well as for patients with a limited family history of CRC or EC and indicates that these patients have the same risk of carrying an MMR mutation as those who meet the revised Bethesda guidelines.

These findings suggest that the current clinical criteria of a personal CRC diagnosis before the age of 50 years may be too restrictive. Table 1 shows that of the patients diagnosed with CRC between the ages of 30 and 74 years with little to no family history, $17.9 \%(1,627)$ of the tested patients and $18.8 \%$ (98) of the positive patients were diagnosed between the ages of 50 and 59 years. Although many of these patients likely met some non-age-based testing criteria (abnormal MSI or IHC), the limitations of molecular testing availability and performance has resulted in continued clinical reliance on the Bethesda guidelines. Therefore, this data shows that a significant number of patients with an elevated risk for LS would have been excluded from genetic testing based on clinical criteria.

This is also reflected in the mutation distribution in all patients, regardless of family history (fig. 2). A proportionately larger number of $M L H 1$ and $M S H 2$ mutations were identified in patients diagnosed before the age of 60 years as compared to those diagnosed after the age of 60 years. This is likely because $\mathrm{MLH1}$ and $\mathrm{MSH} 2$ mutations have higher penetrance, making them more likely to be identified in younger patients. Figure 2 shows that this is coupled with an enrichment of mutations in EPCAM, MSH6, and PMS2 in patients older than 60 years. This suggests that while the distribution of MMR mutations may differ based on age at diagnosis, patients diagnosed before the age of 60 years have an increased likelihood of having LS.

Genetic testing has been well tolerated in patient populations and offers an opportunity to broaden the testing criteria for LS to identify more at-risk patients. Although the revised Bethesda guidelines are considered to be the 'gold standard' for screening appropriate patients for MMR mutation testing, their clinical utility has only been demonstrated in small patient cohorts, and only for the assessment of $M L H 1 / M S H 2$ mutations [15-18]. The data presented here shows that patients diagnosed with CRC between the ages of 50 and 59 years show no statistical difference in positive MMR mutation rate from patients diagnosed before the age of 50 years. The stringent requirements of the current clinical guidelines would have excluded $18.8 \%$ of LS carriers in this cohort of patients with limited or no family history.

\section{Acknowledgements}

We would like to acknowledge the efforts of the clinicians and patients who have made this work possible.

\section{Disclosure Statement}

All authors were employees of Myriad Genetic Laboratories, Inc., during the study period. This analysis was funded by Myriad Genetic Laboratories, Inc.

\section{References}

1 Ligtenberg MJ, Kuiper RP, Chan TL, Goossens M, Hebeda KM, Voorendt M, Lee TY, Bodmer D, Hoenselaar E, Hendriks-Cornelissen SJ, Tsui WY, Kong CK, Brunner HG, van Kessel AG, Yuen ST, van Krieken JH, Leung SY, Hoogerbrugge N: Heritable somatic methylation and inactivation of MSH2 in families with Lynch syndrome due to deletion of the $3^{\prime}$ exons of TACSTD1. Nat Genet 2009;41:112-117.

-2 Lamberti C, Mangold E, Pagenstecher C, Jungck M, Schwering D, Bollmann M, Vogel J, Kindermann D, Nikorowitsch R, Friedrichs N, Schneider B, Houshdaran F, SchmidtWolf IG, Friedl W, Propping P, Sauerbruch T, Buttner R, Mathiak M: Frequency of heredi-

Descriptive Study of Lynch Syndrome Testing tary non-polyposis colorectal cancer among unselected patients with colorectal cancer in Germany. Digestion 2006;74:58-67.

3 Boland CR, Shike M: Report from the Jerusalem workshop on Lynch syndrome-hereditary nonpolyposis colorectal cancer. Gastroenterology 2010;138:2197.e1-e7.

4 Watson P, Vasen HF, Mecklin JP, Bernstein I, Aarnio M, Jarvinen HJ, Myrhoj T, Sunde L, Wijnen JT, Lynch HT: The risk of extra-colonic, extra-endometrial cancer in the Lynch syndrome. Int J Cancer 2008;123:444-449.

5 SEER Cancer Statistics Review, 1975-2011. National Cancer Institute; 2014. http://seer. cancer.gov/csr/1975_2011/.
6 Edelstein DL, Axilbund J, Baxter M, Hylind LM, Romans K, Griffin CA, Cruz-Correa M, Giardiello FM: Rapid development of colorectal neoplasia in patients with Lynch syndrome. Clin Gastroenterol Hepatol 2011;9:340-343.

7 Nagy R, Sweet K, Eng C: Highly penetrant hereditary cancer syndromes. Oncogene 2004; 23:6445-6470.

8 Lin KM, Shashidharan M, Ternent CA, Thorson AG, Blatchford GJ, Christensen MA, Lanspa SJ, Lemon SJ, Watson P, Lynch HT: Colorectal and extracolonic cancer variations in MLH1/MSH2 hereditary nonpolyposis colorectal cancer kindreds and the general population. Dis Colon Rectum 1998;41:428-433. 
9 Weissman S, Burt R, Church J, Erdman S, Hampel H, Holter S, Jasperson K, Kalady M, Haidle J, Lynch H, Palaniappan S, Wise P, Senter L: Identification of individuals at risk for Lynch syndrome using targeted Evaluations and genetic testing: National Society of Genetic Counselors and the Collaborative Group of the Americas on Inherited Colorectal Cancer Joint Practice Guideline. J Genet Counsel 2012;21:484-493.

10 Evaluation of Genomic Applications in Practice and Prevention (EGAPP) Working Group: Recommendations from the EGAPP Working Group: genetic testing strategies in newly diagnosed individuals with colorectal cancer aimed at reducing morbidity and mortality from Lynch syndrome in relatives. Genet Med 2009;11:35-41.

11 Lynch HT, Lynch PM, Lanspa SJ, Snyder CL, Lynch JF, Boland CR: Review of the Lynch syndrome: history, molecular genetics, screening, differential diagnosis, and medicolegal ramifications. Clin Genet 2009;76:1-18.

12 Rodriguez-Bigas MA, Boland CR, Hamilton SR, Henson DE, Jass JR, Khan PM, Lynch H, Perucho M, Smyrk T, Sobin L, Srivastava S: A National Cancer Institute Workshop on Hereditary Nonpolyposis Colorectal Cancer Syndrome: meeting highlights and Bethesda guidelines. J Natl Cancer Inst 1997;89:1758_1762.

13 Umar A, Boland CR, Terdiman JP, Syngal S, de la Chapelle A, Ruschoff J, Fishel R, Lindor NM, Burgart LJ, Hamelin R, Hamilton SR, Hiatt RA, Jass J, Lindblom A, Lynch HT, Peltomaki P, Ramsey SD, Rodriguez-Bigas MA, Vasen HF, Hawk ET, Barrett JC, Freedman AN, Srivastava S: Revised Bethesda Guidelines for hereditary nonpolyposis colorectal cancer (Lynch syndrome) and microsatellite instability. J Natl Cancer Inst 2004;96:261268.

14 Moreira L, Balaguer F, Lindor N, de la Chapelle A, Hampel H, Aaltonen LA, Hopper JL, Le Marchand L, Gallinger S, Newcomb PA, Haile R, Thibodeau SN, Gunawardena S, Jenkins MA, Buchanan DD, Potter JD, Baron JA, Ahnen DJ, Moreno V, Andreu M, Ponz de Leon M, Rustgi AK, Castells A: Identification of Lynch syndrome among patients with colorectal cancer. JAMA 2012;308:15551565.
5 Syngal S, Fox EA, Eng C, Kolodner RD, Garber JE: Sensitivity and specificity of clinical criteria for hereditary non-polyposis colorectal cancer associated mutations in $\mathrm{MSH} 2$ and MLH1. J Med Genet 2000;37:641-645.

16 Wullenweber HP, Sutter C, Autschbach F, Willeke F, Kienle P, Benner A, Bahring J, Kadmon M, Herfarth C, von Knebel Doeberitz M, Gebert J: Evaluation of Bethesda guidelines in relation to microsatellite instability. Dis Colon Rectum 2001;44:1281-1289.

17 Pinol V, Castells A, Andreu M, Castellvi-Bel S, Alenda C, Llor X, Xicola RM, RodriguezMoranta F, Paya A, Jover R, Bessa X: Accuracy of revised Bethesda guidelines, microsatellite instability, and immunohistochemistry for the identification of patients with hereditary nonpolyposis colorectal cancer. JAMA 2005;293:1986-1994.

18 Rodriguez-Moranta F, Castells A, Andreu M, Pinol V, Castellvi-Bel S, Alenda C, Llor X, Xicola RM, Jover R, Paya A, Bessa X, Balaguer F, Cubiella J, Arguello L, Morillas JD, Bujanda L: Clinical performance of original and revised Bethesda guidelines for the identification of MSH2/MLH1 gene carriers in patients with newly diagnosed colorectal cancer: proposal of a new and simpler set of recommendations. Am J Gastroenterol 2006;101:1104-1111.

19 Kievit W, de Bruin JH, Adang EM, Severens JL, Kleibeuker JH, Sijmons RH, Ruers TJ, Nagengast FM, Vasen HF, van Krieken JH, Ligtenberg MJ, Hoogerbrugge N: Cost effectiveness of a new strategy to identify HNPCC patients. Gut 2005;54:97-102.

20 Overbeek LI, Hoogerbrugge N, van Krieken JH, Nagengast FM, Ruers TJ, Ligtenberg MJ, Hermens RP: Most patients with colorectal tumors at young age do not visit a cancer genetics clinic. Dis Colon Rectum 2008;51: 1249-1254.

21 Van Lier MG, De Wilt JH, Wagemakers JJ, Dinjens WN, Damhuis RA, Wagner A, Kuipers EJ, Van Leerdam ME: Underutilization of microsatellite instability analysis in colorectal cancer patients at high risk for Lynch syndrome. Scand J Gastroenterol 2009;44: 600-604.
22 Kastrinos F, Steyerberg EW, Mercado R, Balmana J, Holter S, Gallinger S, Siegmund KD, Church JM, Jenkins MA, Lindor NM, Thibodeau SN, Burbidge LA, Wenstrup RJ, Syngal S: The PREMM $(1,2,6)$ model predicts risk of MLH1, MSH2, and MSH6 germline mutations based on cancer history. Gastroenterology 2011;140:73-81.

23 Perez-Carbonell L, Ruiz-Ponte C, Guarinos C, Alenda C, Paya A, Brea A, Egoavil CM, Castillejo A, Barbera VM, Bessa X, Xicola RM, Rodriguez-Soler M, Sanchez-Fortun C, Acame N, Castellvi-Bel S, Pinol V, Balaguer F, Bujanda L, De-Castro ML, Llor X, Andreu M, Carracedo A, Soto JL, Castells A, Jover R: Comparison between universal molecular screening for Lynch syndrome and revised Bethesda guidelines in a large populationbased cohort of patients with colorectal cancer. Gut 2012;61:865-872.

24 van Lier MG, Leenen CH, Wagner A, Ramsoekh D, Dubbink HJ, van den Ouweland AM, Westenend PJ, de Graaf EJ, Wolters LM, Vrijland WW, Kuipers EJ, van Leerdam ME, Steyerberg EW, Dinjens WN: Yield of routine molecular analyses in colorectal cancer patients $\leq 70$ years to detect underlying Lynch syndrome. J Pathol 2012;226:764-774.

25 Alexander J, Watanabe T, Wu TT, Rashid A, Li S, Hamilton SR: Histopathological identification of colon cancer with microsatellite instability. Am J Pathol 2001;158:527-535.

26 Shia J, Ellis NA, Paty PB, Nash GM, Qin J, Offit K, Zhang XM, Markowitz AJ, Nafa K, Guillem JG, Wong WD, Gerald WL, Klimstra DS: Value of histopathology in predicting microsatellite instability in hereditary nonpolyposis colorectal cancer and sporadic colorectal cancer. Am J Surg Pathol 2003;27:1407-1417.

27 Smyrk TC, Watson P, Kaul K, Lynch HT: Tumor-infiltrating lymphocytes are a marker for microsatellite instability in colorectal carcinoma. Cancer 2001;91:2417-2422.

28 van Putten PG, van Lier MG, Hage M, Biermann K, van Rijssel RH, Westenend PJ, Morreau $\mathrm{H}$, Steyerberg EW, Dinjens WN, Kuipers EJ, van Leerdam ME, van Krieken JH: Limited diagnostic value of microsatellite instability associated pathology features in colorectal cancer. Fam Cancer 2014;13:351-359. 